\title{
HUMAN RIGHTS UNDER THE UNITED NATIONS CHARTER*
}

\author{
BENJAMin V. Cohen†
}

In I942 the American Law Institute undertook to produce a draft of an International Bill of Rights in preparation for the. peace settlement. After working for nearly two years, its committee, without attempting to complete a formal draft, made a report and statement of essential human rights. I know that this work was very helpful to the Department of State in its own preparatory work in this field. These efforts, together with those of other public and religious groups, were also a signifcant factor in influencing our government to take a very active part in writing into the Charter of the United Nations principles of human rights and fundamental freedoms, and in charging the United Nations with the responsibility for promoting respect for and observance of these principles.

The problems arising from the incorporation into the Charter of these principles, some of which I shall discuss, are therefore problems in which we all have taken a part and as to which we all share a responsibility. It is a responsibility, I think, that we should accept not regretfully but with pride, and with determination to realize our high purposes.

The Institute during the war responded to a genuinely felt need concerning the question of human rights. The need is not so keenly felt by us here today, but it is no less keenly felt by many, less fortunate than ourselves, throughout the world. We have a responsibility which we cannot shirk. The responsibility of being one of the strongest and most influential powers in the world is an awesome responsibility and sometimes an irksome responsibility. It would be more pleasant for us to till in our own garden. But the locusts come from afar.

Of course it is important not to neglect our own garden. History and experience, however, have taught us that we cannot long live undisturbed in our own garden if we ignore our responsibility to others. We know we have the capacity in case of necessity to wage war with telling effect. We have to learn to acquire a capacity to wage peace with comparable effectiveness when the need is equally great but is felt not nearly so keenly or so poignantly.

It is interesting to recall that at the Dumbarton Oaks Conference, where the preliminary working draft of the Charter was prepared, relatively little attention was given to the question of human rights and fundamental freedoms. The emphasis was on determining the relations between large and small states and the rules to

- This paper is an address given before the American Law Institute on May 20, 1949.

† Member of the American Delegation, United Nations General Assembly; formerly counscllor of the State Department. 
govern their representation and voting in the various governing bodies. There was a tendency to avoid the problem of human rights.

Some of us became concerned that the Charter towards which we were working might, like the Constitution of the United States as it emerged from the Federal Convention, omit any mention of the principles of human rights and fundamental freedoms. We were told, however, that to inject this subject into the Charter would cause the Soviet Union to fear intervention in its domestic affairs. We were told that the British would fear that reference to fundamental freedom would somehow have serious complications for their colonial relationships. But we persisted and succeeded in incorporating a brief reference in the Charter to the responsibility of the United Nations to promote respect for human rights and fundamental freedoms. The great powers thus became committed.

A number of religious and other public groups, however, were deeply disappointed that we had not accomplished more at Dumbarton Oaks. Some of them wished to see an International Bill of Rights made an integral part of the Charter. It soon became evident, however, to these groups, that this was not within the realm of practical accomplishment. They decided to concentrate their efforts, therefore, on securing in the Charter a more definite commitment to promote the observance of human rights as a basic obligation of the Charter. To this end they proposed the establishment of a Commission on Human Rights and Fundamental Freedoms whose first task should be to prepare an international definition and declaration of human rights.

On February 4, 1945, some time prior to the San Francisco Conference, their program was presented in a radio address by The Honorable John W. Davis. In that address Mr. Davis said:

The proposal I have just read to you urges the setting up of a Commission on Human Rights and Fundamental Freedoms ... It is a necessary part of permanent peace, for there can be no such thing as lasting peace that is not founded on the decent treatment of human beings.

What Mr. Davis said then is no less true today. The program that he presented was vigorously sponsored and supported by virtually all the consultants representing non-governmental organizations cooperating with our government in San Francisco. They included leaders of the three great faiths, leaders of business, of labor, and of agriculture. Indeed, this program resulted not from the efforts of leaders in our government to stir up public support but from their response to a very keen and active public sentiment that then existed in this country. The program indeed had such public appeal that it was in the main not only accepted by our government but by other governments at San Francisco.

The Charter called, as you may remember, for the setting up of a commission to promote human rights, and the United Nations Human Rights Commission was constituted during the first session of the General Assembly. It took this Human 
Rights Commission over two years to elaborate a Declaration of Human Rights which was submitted to the General Assembly at Paris last fall. There a committee of the Assembly worked over this Declaration for months and made many amendments. The Assembly then accepted the Declaration as amended without a dissenting vote, and only eight members abstained.

It is significant that there was so much of impelling appeal in the Declaration to the peoples of all countries that not a single country ventured to register a negative vote.

The Declaration is not a treaty. It is not legally binding upon the members of the United Nations. But it is what it is stated to be-a universal Declaration of Rights proclaimed by the General Assembly to be

a common standard of achievement for all peoples and all nations, to the end that every individual and every organ of society, keeping this Declaration constantly in mind, may strive by teaching and education to promote respect for these rights and freedoms, and by progressive measures, national and international, to secure their universal and effective recognition and observance both among the peoples of member states themselves and among the peoples of territories under their jurisdiction.

The Declaration may not be perfect. Indeed it is not perfect. It is not written exactly as any national delegation that collaborated in its drafting would have written it. There may be debate as to the meaning and content and the most appropriate implementation of its provisions as there is still debate as to the meaning, content, and most appropriate implementation of our own national Bill of Rights. The significant thing about the Declaration is that it is a beginning and not the culmination of mankind's effort on an international basis to promote human rights and fundamental freedoms.

Doubts have been expressed by some leaders of public opinion in this country as to the appropriateness of the inclusion of certain so-called social rights in the Declaration. It is not without significance, however, that such rights were included in the statement of essential human rights prepared under the guidance of the Committee set up by the American Law Institute. Such rights are also included in the Declaration of the Rights and Duties of Man adopted last year at Bogota by the International Conference of American States.

It is a grievous mistake, I think, to assume that the inclusion of these rights in the Declaration means that these rights must be secured exclusively or even primarily by direct state action. It seems to me unfortunate that those of us who think that our economic system has advantages over the systems of other states should even unintentionally cast doubt upon the proposition that one of the chief objectives of our system is to satisfy the needs that are reflected in the demand for social rights.

It is the plan of the Human Rights Commission to continue its work on a Covenant of Human Rights to take a form of convention which, when ratified, would become legally binding on the adhering states. Obviously, to be susceptible of legal 
interpretation and to obtain ratification, the Covenant will have to be much more limited in scope and more definite in content than the Declaration. In order to distinguish the Covenant from the Declaration there might be advantages in calling it a Covenant of Civil Rights rather than Human Rights. Indeed, it remains to be seen just how far we can go in obtaining general agreement on a legally binding Covenant which will not wash out the substance of the rights which we may wish to make legally secure.

Work on the Covenant, therefore, should not obscure the continuing value of the Declaration. The principles of the Declaration of Independence have not the force of law, but they remain a source of continuing inspiration to us. The various restatements of law prepared by the American Law Institute have not the force of law, but they have had, and I hope may continue to have, a very salutary effect on the development of law and juristic thought. So it can and should be with the Declaration of Human Rights. Without having the force of law, the Declaration of Human Rights does provide standards in support of which world opinion can and should be rallied.

World law to be effective must be rooted in sentiments deeply cherished throughout the world and not simply in national sentiments however strong they may be in some countries. Law can and should stimulate conscience; but it can do so only within limits. World law to be effective must be backed by world opinion and the conscience of mankind. If -and only if-we develop a universal conscience can we have universal law.

In addition to the efforts which will be made in the United Nations for the conclusion of a Covenant of Human Rights, there is also need for effort on a national basis to give effect to the moral and political values of the Declaration. It would, for example, be very helpful if the General Assembly should call upon all member states to create national Human Rights Commissions to report periodically to their respective national governments, and through those governments to the United Nations, on what is being done and what further might be done in their respective countries by teaching, education, and progressive measures to make human rights and freedoms more secure. Such national commissions might also consider and recommend clarifications, additions, and amendments in the Declaration itself.

Through such national commissions we should be able to adapt and apply the basic principles of the Declaration to the living and growing traditions of different nations. Through such a system of self-policing under the general guidance of the General Assembly, functioning as the forum of world opinion, we should be able to make substantial progress towards the recognition and observance of human rights, and avoid, as far as practicable, the perplexing question of international interference in domestic affairs.

In this way we can use the Declaration as a means of awaking the conscience of men and women all over the world. In this way we can use the Declaration not as a means of imposing the will of some nations on other nations, but of assisting 
all nations to protect and defend the freedom of their own citizens. For the Declaration to be effective it must command the willing allegiance of mankind. The Declaration can and should serve to unite men of all nations, because it gives expression to their common aspirations.

But apart from the Declaration and the work of the Human Rights Commission, the mere incorporation into the various parts of the Charter of the responsibility devolving upon the United Nations to promote respect for and observance of human rights and freedoms has already brought to the Assembly important and perplexing problems.

At the last session three cases were on the agenda involving alleged violations of human rights and freedoms. One brought by Chile concerned the refusal of the Soviet Union to permit the Soviet wife of the Chilean Ambassador's son to leave the Soviet Union. Another, brought by Australia and Bolivia, alleged systematic suppression of civil and religious liberties in Bulgaria and in Hungary in violation of the Charter and peace treaties, and referred specifically to the recent trials of church leaders in those countries. A third, brought by India, alleged discrimination against persons of Indian origin in the Union of South Africa. In all three cases the states against which the complaints were directed contended that the cases should not have been admitted to the agenda because the mere consideration of the cases involved intervention in matters essentially within their domestic jurisdiction.

As lawyers we might find plausible grounds for distinguishing among these cases, but there is not time for us here to go into those distinctions. The Assembly was satisfied that it was within its competence to discuss all three cases. Although resolutions were passed in all three cases there were considerable differences of opinion as to how far it was proper for the Assembly to go in its resolutions. And it cannot be said that all members maintained a consistent position in all three cases. Indeed it might be said that some states maintained an inconsistent position and voted in accordance with their predilections rather than in accordance with any discernible principle.

The American delegation took the position that "practical statesmen would not have written human rights and fundamental freedoms all over the Charter, as they did, if it had been their intention to take all discussion of human rights and freedoms out from under the Charter." We did not consider that the injunction against intervention in domestic affairs was intended to put an absolute ban on the consideration of matters relating to human rights in connection with the appropriate consideration of conditions affecting the friendly relations between states. In such circumstances we did not believe that the Assembly was barred from expressing a hope that a certain procedure might be followed which might be helpful to compose differences and bring about agreement and constructive settlement.

We frankly stated that it was not easy to determine with precision what constitutes intervention in domestic affairs, or what sort of deliberate and systematic 
disrespect for or disregard of human rights takes a matter out from the realm of domestic concern and makes it a matter of international concern. We consciously endeavored to avoid committing ourselves to any hard or fast rule which would close the door to the progressive development of principles of international law in this field.

We did, however, give warning that it was a part of statesmanship to proceed cautiously in this delicate field of human rights and fundamental freedoms so as to avoid serious repercussion on sensitive domestic policies and strong reaction against wholesome international efforts in this field.

In view of the serious constitutional questions involved, we urged the greatest self-restraint in passing upon frailties which in varying degrees we all share. In the Mindszenty case, speaking on behalf of the United States delegation, I stated:

Generally speaking ... no organ of the United Nations can compel corrective action in this field in the absence of a breach of or a threat to international peace, or of a treaty providing for such action.

Serious responsibility rests upon members of the Assembly to refrain from making recommendations which may not only be ignored but may in fact in certain situations create greater intransigence on the part of those criticized and aggravate the position of those most deserving of our sympathy and assistance. The task of the Assembly is to promote respect for and observance of human rights and fundamental freedoms and not to make recommendations which in fact defeat the practical realization of its objectives.

Moreover, the General Assembly obviously cannot itself act as a court to review all the individual cases in which it may be alleged that human rights and freedoms have been infringed. But appreciation of the practical difficulties in promoting respect for and observance of human rights should not and cannot be exploited as an easy excuse for not trying to do anything in any situation.

It will require a great deal of time and concerted effort to establish adequate minimum standards of respect for human rights and freedoms everywhere in the world as envisaged in the Charter. The General Assembly rightly took as its first step the working out of a general Declaration of Human Rights so that we may have some standards with which to start. In all of our countries, including our own, much remains to be done, and none of us can afford to assume a self-righteous attitude. But if we are serious in our quest for peace we cannot fail to do our part and make every effort towards promoting minimum standards of human rights.

There are in this changing and diversified world, varying concepts of the functions of the state and the status of the individual. We generally agree that within the widest limits the rights of the individual in relation to the state should be determined by the respective states. But there are limits.

I think we are all in agreement that, in light of our pledges in the Charter, the functions of the state should be of a character to promote and not destroy human rights and fundamental freedoms. Let us grant that in the absence of a treaty we must accept the judgment of the respective states as to what functions of the state promote the rights and freedoms of its citizens and what is the exact substantive content of these rights and freedoms; there is, nevertheless, an obligation on the part of every civilized state to exercise its judgment in honesty and in good faith. No state has the sovereign right 
claimed by Hitler's Third Reich to declare war on freedom and religion. State sovereignty does not mean state tyranny.

It seems to me that the very practical problems which have already confronted us in the Assembly show the importance of clearer understanding of and more widespread agreement on minimum standards of international and human rights. I know there are those who minimize the importance or value of introducing standards of human rights into the field of international relations. Even the distinguished President of the American Bar Association, Mr. Holman, has expressed the view that the first and second World Wars were not caused by the absence of an international Bill of Rights and that the existence of one now will not assuredly contribute to world peace. I hesitate to differ with such eminent authority, and I am not sure that our differences, important as they may be, are not differences in emphasis rather than in substance. It is true that problems of war and peace are affected by many forces and circumstances. Dogmatism on issues which so vitally affect the well-being of hundreds of millions of people is certainly to be avoided. And I agree, of course, that no paper Declaration of Rights is going automatically to prevent war. But if we can by teaching, education, and progressive measures make the Declaration of Human Rights mean something, make it a part of the conscience of mankind, it will in my judgment be difficult to exaggerate the effect it can have upon the growth of tolerance and understanding of differences.

Tolerance and understanding of differences are, in my judgment, indispensable conditions for enduring peace in this world, populated by many different peoples with diversified beliefs and ideologies. I venture to say that if there had been an International Bill of Rights after the first World War, and if the nations had measured seriously the events of those years by the declared standards, the second great conflict might have been avoided.

If there was error in not recognizing sooner the encroachment on human rights in Europe before the recent war, let us not repeat that error now. I think it means a great deal to us and to our position in the world that we should be regarded as leaders and not slackers in the struggle for human freedom.

General Marshall is certainly no starry-eyed dreamer. At the opening session of the General Assembly in Paris last fall he stated:

Systematic and deliberate denial of basic human rights lies at the root of most of our problems and threatens the work of the United Nations. It is not only fundamentally wrong that millions of men and women live in daily terror of secret police, subject to seizure, imprisonment, and forced labor without just cause and without fair trial, but these wrongs have repercussions in the community of nations. Governments which systematically disregard the rights of their own people are not likely to respect the rights of other nations and other people, and are likely to seek their objectives by coercion and force in the international field.

There is no question that in this world where ugly forces are loose we must maintain our strength and not allow weakness to invite aggression. But strength 
alone is not enough. Strength alone affords no basis for enduring peace. It must be strength in the service of great ends, the ends for which our country was founded, the ends for which successive generations of Americans have given their lives.

To provide a basis for enduring peace, our foreign policy must be positive and creative and not negative and inert. To characterize the objectives of our foreign policy as the containment of Soviet Russia or the containment of Communism is not enough. That fails to distinguish adequately and clearly our policy from that of the Soviet Union. I suppose the policies of the Soviet Union might in a sense be described as the policy of containing the United States, or of containing capitalism. Our policy should be based upon principles of law and morality; our powers should be exercised in behalf of justice, freedom, health, and human dignity. These principles we can and should uphold on both sides of the Iron Curtain. Nothing will do more to make clear our devotion to these principles than a policy which strives to secure the effective recognition and observance of human rights and fundamental freedoms for all peoples. No policy better accords with the traditions which have made us and kept us a nation of free men and free women. 